Swarthmore College

Works

\title{
Optional Online Research Projects On Four Stories In Sandra Cisneros' "Woman Hollering Creek And Other Stories"
}

Peter Schmidt

Swarthmore College, pschmid1@swarthmore.edu

Follow this and additional works at: https://works.swarthmore.edu/fac-english-lit

Part of the English Language and Literature Commons

Let us know how access to these works benefits you

\section{Recommended Citation}

Peter Schmidt. (2017). "Optional Online Research Projects On Four Stories In Sandra Cisneros' "Woman Hollering Creek And Other Stories"'". English Literature Faculty Works. DOI: 10.24968/2476-2458.engl.361 https://works.swarthmore.edu/fac-english-lit/361

\section{(c) (1) (8)}

This work is licensed under a Creative Commons Attribution-Noncommercial 4.0 License This work is brought to you for free by Swarthmore College Libraries' Works. It has been accepted for inclusion in English Literature Faculty Works by an authorized administrator of Works. For more information, please contact myworks@swarthmore.edu. 


\title{
Optional Online Research Projects on Four Stories in Sandra Cisneros' Woman Hollering Creek and Other Stories: "Eleven," "Barbie-Q," "Little Miracles, Kept Promises," and "Woman Hollering Creek"
}

\author{
Peter Schmidt \\ Department of English Literature \\ Swarthmore College
}

For High School and College/University Students and Their Teachers

[Note: this essay is intended to supplement one that will be published in the Modern Language Association's Options for Teaching series: Teaching the Narrative of Mexicana and Chicana Writers. Ed. Elizabeth Martínez, DePaul University. Publication date to be announced; probably 2018 or 2019.]

\section{Optional Online Student Research Projects for "Barbie-Q"}

The story refers to the famous Maxwell Street market in Chicago. Have students do online research on the history of the market, where they can discover that it was dismantled in 1994. What communities and classes did this market serve? What caused its dismantling? Have the students list at least 4 or more facts they learned about the market's importance. Ask them then to discuss how knowing such historical facts enhance our understanding of Cisneros' story. If they don't find it on their own, have the students study Wikipedia's page on the history of the market: https://en.wikipedia.org/wiki/Maxwell_Street

Explore the barbie.mattel.com and shop.mattel.com/Barbie websites, where their slogan is "Where we are creating the future of play!" How is the company currently marketing its Barbie dolls? How has the Barbie product changed since it was first introduced in the 1960s? How does doing research on Mattel's online Barbie websites help students appreciate Cisneros" "Barbie-Q"?

For advanced students, have them do further research on debates about how to understand mass market popular culture and how consumers interact with it. Key names: Max Weber, Walter Benjamin, Theodor Adorno, Antonio Gramsci, Pierre Bourdieu, Stuart Ewan, Dick Hebdige, George Lipsitz. Key concepts: Weber on the status group; Benjamin on the revolutionary potential in pop culture; Adorno on pseudo-individuality and conformity; Gramsci on hegemony; Bourdieu on taste and cultural capital; Hebdige and George Lipsitz on youth subcultures, resistance, and community-building.

Have students search online using a theorist's name and one of the concepts above associated with him. Help the students interpret the materials they find online.

Have students explore whether the girls' behavior in Cisneros' story sometimes challenges these theories or at least shows them to be incomplete. If we read this story as 
an example of how consumers have their imaginations commodified, which theorist or theorists in this group has a cultural model that best explains what happens? If we interpret Cisneros' story to show the opposite - that is, that the girls make something new, rather than just following pre-made scripts, and that their play unconsciously initiates a radical critique of social hierarchies, not merely learning their "place"-which theorist or theorist best describes why that behavior of the girls is important?

Here's one example. Does "Barbie-Q" challenge Bourdieu's proclamation that "[Taste] functions as a sort of social orientation, a 'sense of one's place,' guiding the occupants of a given ... social space towards the social positions adjusted to their properties, and towards the practices or goods which befit the occupants of that position" (Distinction: A Social Critique of the Judgment of Taste, 466)? (Bourdieu's claim is extremely deterministic, is it not?)

Regarding the debate at the core of the Frankfurt School, a good place to start is an excellent, accessible, and brief essay by Alex Ross in The New Yorker: "The Naysayers: Walter Benjamin, Theodor Adorno, and the Critique of Pop Culture." http://www.newyorker.com/magazine/2014/09/15/naysayers

For further exploration of and historical perspective on debates about the function and effects of popular culture on those who consume it, a lucid guide is Robert Parker's essay (see Works Cited).

For students who have read other Cisneros writings, have them compare and contrast this story's treatment of popular culture and brand names with those in other fiction or poetry of hers.

\section{Optional Online Student Research Projects on "Little Miracles, Kept Promises": On milagritos, the story's Frida Kahlo allusion, and other topics. For the relevance of Tonantzín, see the optional student research projects below on "Woman Hollering Creek."}

Cisneros' story seems carefully ambiguous regarding exactly where this story takes place - other than that the milagrito notes mention various cities and towns in Texas. Use an online map to locate the locations mentioned in Cisneros' story: what do you discover?

Have students do online or library research, looking for images illustrating milagritos. Have them also find images of various retablos (votive displays often picturing male and female saints), both ones in public places like churches and ones in homes or other spaces. (Not the home and garden decor company with that's named Retablo, or other false leads!) Have students display and discuss in class the best images they find. Where are the retablos located? What function do they have? When one worshipper adds her or his thank-you milagrito to hundreds of others, how might that help the healing process?

For advanced students, have them read part or all of Ana María Pineda R.S.M.'s article, "Imagines del Dio en el Camino: Retablos, Ex-Votos, Milagritos, and Murals," 
Theological Studies 65 (2004): 364-79. Web:

http://cdn.theologicalstudies.net/65/65.2/65.2.6.pdf

Pineda's article mentions that in many towns and cities, the practice of displaying painted images of dramatic events and making retablos and ex-votos honoring saints have spread from the churches to public plazas and even homes. All these displays take different forms but are united by combining 2-D or 3-D images with stories.

Have students discuss the implications of the passage below from Pineda, p. 378. In what ways does Cisneros' "Little Miracles" support Pineda's claim that the Latino/a community is both conforming to tradition Catholic forms of worship and giving thanks, but also adapting those rituals for other spaces outside of a particular church, spaces both public and private?

"The ancient arts of retablos, ex-votos, and milagros coupled with the realities lived by Latino communities in the U.S. are producing new sources/expressions of spirituality and art for U.S. Latinos/Hispanics. The public nature of murals points to the migration of the sacred from the enclosed spaces of the church to the streets of the barrio. The activity that takes place along the border with retablos, ex-votos and milagritos are strong indicators of the creative ways that Latinos seek in order to be in touch with the sacred. As Allan Figueroa Deck writes in this issue of Theological Studies, faith cannot become deep or authentic until it really penetrates the profound significance of the symbols, rituals and metanarratives of a people. Yet, as Figueroa Deck further argues, the Church's discomfort with Latino popular religion and worship is creating a greater disconnect between Latinos and Roman Catholicism.”

\section{The Frida Kahlo allusion in "Little Miracles, Kept Promises"}

Chayo's entire section of the story (pp. 124-29) is presented as a long "note" or prayer to La Virgen de Guadalupe, accompanying a long "braid" of Chayo's hair that she's cut off and pinned to La Virgen's statue, signifying thanks for giving Chayo the strength to begin a new life as an artist (124).

Chayo's cutting her hair is reminiscent of an event commemorated in one of Frida Kahlo's most famous paintings. After divorcing Diego Rivera for being unfaithful, Kahlo depicted herself wearing an oversize man's suit and having cut off all her hair. "Self-Portrait With Cropped Hair" quotes a popular Mexican song about what makes men love women: "Mira que si te quise, fué por el pelo, Ahora que estas pelona, ya no te quiero" ("Look, if I loved you, it was for your hair; now that you're bald, I don't love you any more"). See below: 


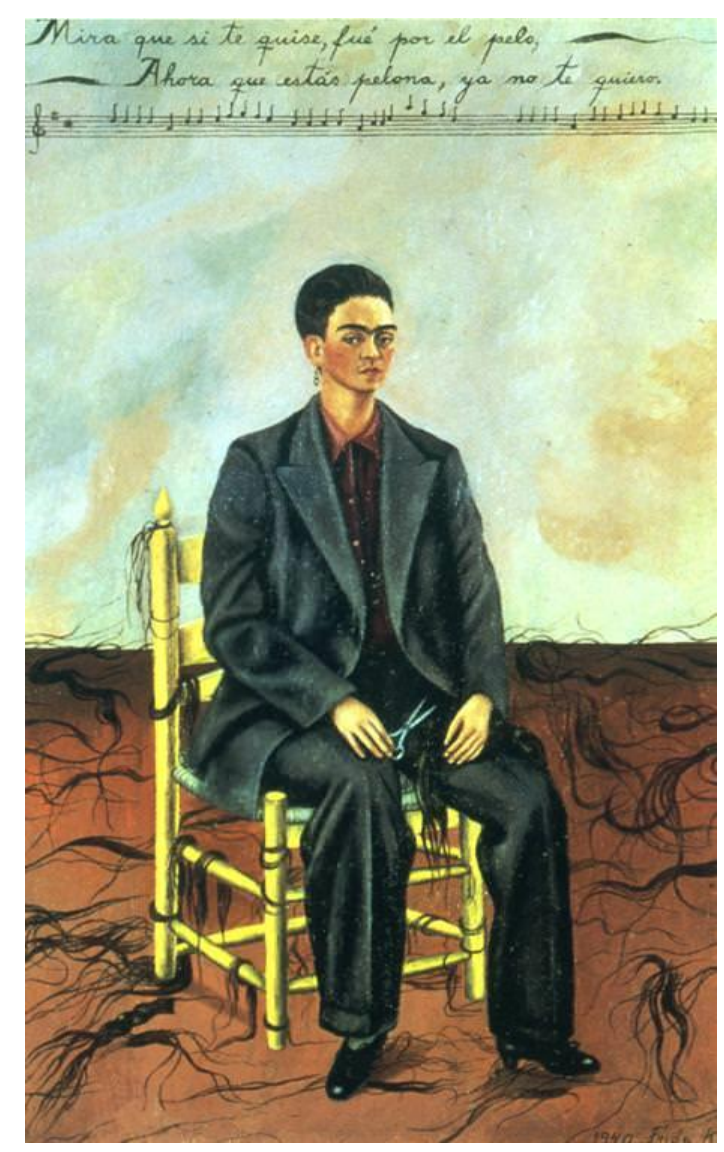

\section{Discussion questions:}

How would students interpret Kahlo's self-portrait as a response to her divorce? Does it mean that she now believes that an independent woman artist must be understood to be "masculine"? Or is she criticizing men, particularly her former husband, for their "male gaze," the expectations they have for how women should appear and behave? Does the portrait show Kahlo as lost or confused, or do they feel the painting expresses anger and satire directed both toward her former husband and towards Mexican culture in general?

As Mexico's most famous female artist, Frida Kahlo is, not surprisingly, inspirational for Chayo, who also wants to be a painter. In what ways does Chayo's act of cutting her hair differ from Kahlo's? What has allowed Chayo to have a different understanding of the meaning of cutting her hair? Rivera (48) interprets the gift of her cut braid to La Virgen as signifying "rebirth," stressing this quotation of Chayo's: "my head as light as if I'd raised it from water" (Woman Hollering Creek 125). 


\section{Further Discussion Questions and Optional Online Research Topics on La Llorona, La Malinche, and Tonantzín for "Woman Hollering Creek"}

\section{Are there two different endings to "Woman Hollering Creek"?}

The last words of the story suggest Cleófilas has begun to find a new, less passive "voice" and a vision of who she can be as a woman. Yet we also know from the story's final page - the sentence that begins, "Can you imagine it?"- that although Cleófilas successfully escapes back to Mexico, she returns to a household still ruled by men's needs. In fact, the end of the story loops back to the story's first paragraph, when Cleófilas' return is prophesied by her father: "already did he divine the morning his daughter would raise her hand over her eyes, look south, and dream of returning to the chores that never ended, six good-for-thing brothers, and one old man's complaints" (43). In short, Cleófilas seems bound by patriarchy and its demands, regardless of which side of the México/U.S. border she resides.

In short, we might say that "Woman Hollering" gives us two different endings in tension with each other. One focuses on Cleófilas's escape from entrapment in patriarchy and the transformation of her voice and her consciousness; it also sketches out a community of women who look out for each other (most notably represented by Gabriela and Felice). Cisneros' "other" ending suggests that Cleófilas' fate is an eternal return to male-dominated spaces and suffering. This is not an ending that sounds like the creek's name to Cleófilas when first hears of it, "so pretty and full of happily ever after" (47).

Is Cisneros' double ending appropriate to "Woman Hollering Creek"? Why or why not?

As well as telenovelas, Mexican legends about dangerous women dominate this and other stories in Cisneros' collection: La Llorona, La Malinche, and Tonantzín. Have students look up summaries of these women and their stories. Who are they, what do their legendary names mean, and what happens to these women? What different "morals" do these legends teach?

Wikipedia has decent pages devoted to background information on these three figures:

https://en.wikipedia.org/wiki/La_Llorona https://en.wikipedia.org/wiki/La_Malinche https://en.wikipedia.org/wiki/Tonantzin

More ambitious students researching these references in Chicana literature may turn to Rivera $(45,48-49)$ and books by Virginia Brackett, Tey Diana Rebolledo, and Philippa Kafka (see Works Cited below).

Two goals that should guide any discussion involving La Llorona, La Malinche, and Tonantzín:

- to have students realize the function of a cautionary tale, and

- to have students understand that sometimes even tales meant to be negative examples of bad behavior may hold hidden, opposite meanings. 
Brief commentary for teachers: the La Llorona and Malinche stories in particular function as cautionary tales telling girls and women what not to become. They emphasize the negative consequences that follow a woman who doesn't conform to the "proper" woman's role as self-sacrificing wife or pure virgin. They also warn a bout happens to a woman who "crosses" or mixes worlds, cultures, or languages - as did La Malinche, aka Malintzín (Hernán Cortez's translator). She becomes a figure of guilt, shame, and censure; a traitor (La Malinche); or a kind of non-maternal ghostmonster who takes life rather than gives it (La Llorona).

But as the narrator slyly suggests early on in "Woman Hollering Creek," the woman for whom the creek is named after may have hollered from anger (46). Perhaps she was questioning the way things are, not accepting her fate?

A lengthy, detailed reading of "Woman Hollering Creek" - with particular emphasis on its complex, evolving structure and its flexible time and space references-is James Phelan's Experiencing Fiction: Judgments, Progressions, and the Rhetorical Theory of Narrative, pp. 165-177.

What do students think of this conclusion of Phelan's?

"Thus, in crossing the physical border marked by the creek, Cleofilas also crosses a psychic border and Cisneros crosses a mythic border, adding the story of "La Felice" to the narratives surrounding "La Malinche" and "La Llorona." (176)

If students agree with Phelan's reading, what is the value of "crossing borders? Does La Felice's story merely add to the stories of La Malinche and La Llorona, or does it significantly transform how we may understand those stories, giving us an alternative interpretation of a woman who crosses cultural borders or transgresses?

For another discussion of the ending of "Woman Hollering Creek" and Felice's "voice" in Cleófilas' throat, see Rivera 45. Note: in Spanish you can mark a woman's importance or authority by adding "La" to her first name, so that she becomes "La Felice," not just "Felice." This can be done with saints and deities too, as in "La Virgen."

\section{CONCLUSION}

Two more general research questions on all the stories in Woman Hollering Creek. For advanced students.

\section{The first involves Cisneros' use of Spanish and English:}

Some (not all) of Cisneros' stories use both Spanish and English, with English words well outnumbering the words in Spanish. Some of the Spanish quoted is standard Spanish, but at other times Cisneros uses Mexican or Chicano slang. But these two 
languages interact in her stories in different ways. Cisneros will sometimes give an immediate translation of a Spanish term or phrase, but many times she will not. Sometimes Cisneros will italicize the Spanish words, marking them as an "other" language. But other times she will not italicize Spanish. Does that place the two languages on more equal footing? For examples of the latter, see "Little Miracles," pp. 122-23.

Most interesting of all, perhaps, are the occasions where Cisneros' English seems not just to include occasional Spanish words, but to be itself actively marked by the unseen presence of Spanish, as if the English we read is "translated" from the Spanish.

These interactions between Spanish and English cover a spectrum of possible relations. At one extreme (but common in Cisneros' work), Spanish is incorporated sparingly and a translation is immediately made, thus signifying that the story very much wants to make itself accessible to an English-only reader. At the other end of the spectrum, Cisneros' use of Spanish sometimes assumes that a) the English-only reader is willing to do the research to learn the meaning of the Spanish term, and perhaps also to the cultural practice to which it refers; and that b) only someone fluent in español will fully appreciate the Spanish idioms and inflections hidden in Cisneros' English.

Examples in the "a" group give most power to English-speaking readers; examples " $b$ " reverse that and make Spanish occasionally dominant, sometimes in ways that will be very difficult for English-only readers to "hear" unless it is pointed out to them.

These instances of linguistic "crossings" in Cisneros' texts are also extremely hard to represent in a Spanish-only translation of Cisneros, particularly in the case of the second of the group "b" examples given above.

For Spanish-speaking readers, there's a good discussion of all of these examples, and many more, in the following article: María Laura Spoturno, "La traducción literal como estrategia desterritorialización y caso especial de alternancia des lenguas en Woman Hollering Creek de Sandra Cisneros" ["Literal Translation as Strategy of Deterritorialization and a Special Case of Code-Switching in Sandra Cisneros' Woman Hollering Creek"]. Trans: revista de traductología 14 (January 2010): 63-82. [Málaga, Spain]

Spoturno argues that even literal translation deterritorializes the spaces of English and Spanish, unsettling or blurring expected power relations between "dominant" and "translated" languages. Her article parses many different examples of code-switching and translation in Cisneros' stories, with particular focus on "Eyes of Zapata" and "Bien Pretty."

A copy of Spoturno's essay may be obtainable via Interlibrary loan, or Peter Schmidt can send you a copy of my pdf if requested (for teachers and nonprofit and/or "fair use" only). Email me using the information available on my Swarthmore.academia.edu website.

For other discussion of Cisneros' use of Spanish and English, see Mullen and Rivera (49-50). I particularly recommend considering carefully the following complex point of Mullen's, cited by Rivera (49):

"That Spanish operates both as an insider code comprehensible to some but not to others, and also as a repressed language in its subordination to English 
as the dominant language in the U.S., might be read as the primary signification of the entire text of Woman Hollering Creek. ...The untranslatability of the beauty of Spanish, the unpronounceability of Spanish and Amerindian names on the gringo tongue, and the invisibility or discursive silencing of Chicanos, are all figured in Cisneros' text."

For a strong general argument in favor of not having an author translate all "foreign" words to make it easy on a monolingual reader, see Dasenbrock.

\section{A second research topic focuses on Cisneros' occasional references to an African diasporic influence on Mexican and Chicano cultural practices. Here is the most prominent example, from "Little Miracles, Kept Promises":}

- The milagrito prayer that begins, "Seven African Powers that surround our Savior - Obatala, Yemaya, Ochún, Ogun, Elegua, and Shango — why don't you behave and be good to me? Oh Seven African Powers..." (119).

Chayo's list near the end of the story (p. 128) of Tonantzín's many other incarnations doesn't refer to African gods per se, but it does include many other world religious traditions, including Buddhism, Judaism, and Islam.

Research online the African presence in Mexico and Mexican history, particularly in Mexico's northeast provinces and in Yucatán. How does your research help us understand Chayo's (and Cisneros') interest in understanding Mexican culture and history as profoundly hybrid?

To explore Afro-Mexican culture and history, see also print works by Anita González, Herman L. Bennett, and Chege J. Githiora (cited below).

\section{WORKS CITED}

Adorno, Theodor W., and Max Horkheimer. "The Culture Industry: Enlightenment as Mass Deception." Dialectic of Enlightenment. Transl. John Cumming [1944]. New York: Herder and Herder Press, 1972. 120-167. Rpt. with a new translation in Dialectic of Enlightenment: Philosophical Fragments. Transl. Edmund Jephcott. Stanford: Stanford University Press, 2002. 94-136.

Bennett, Herman L. Colonial Blackness: A History of Afro-Mexico. Bloomington, Indiana: University of Indiana Press, 2009.

Bourdieu, Pierre. Distinction: A Social Critique of the Judgment of Taste. New York: Routledge, 1984. 
Brackett, Virginia. A Home in the Heart: the Story of Sandra Cisneros. Greensboro, North Carolina: Morgan Reynolds Publishing, 2005.

Cisneros, Sandra. Woman Hollering Creek and Other Stories. New York: Random House, 1991.

Cisneros, Sandra. A House of My Own: Stories From My Life. New York: Knopf, 2015.

Dasenbrock, Reed Way. "Intelligibility and Meaningfulness in Multicultural Literature in English.” PMLA 102.1 (January 1987): 14-15.

Githiora, Chege J. Afro-Mexicans: Discourse of Race and Identity on the African Diaspora. Trenton, New Jersey: Africa World Press, 2008.

González, Anita, and Ben Vinson. Afro-Mexico: Dancing Between Myth and Reality. Austin, Texas: University of Texas Press, 2010.

Gonzáles-Berry, Erlinda. "Review of Woman Hollering Creek and Other Stories, by Sandra Cisneros." The Americas Review 20.1 (Spring 1991): 84-85.

Joysmith, Claire. 'Cuchicheos, Gritos y Silencios: Transbordering Sandra Cisneros' Woman Hollering Creek into México y el Español.” FIAR: Forum for InterAmerican Research 5.1 (April 2012).

Kafka, Philippa. (Out)Classed Women: Contemporary Chicana Women on Inequitable Gender Power Relations. Westport, Conn.: Greenwood Press, 2000.

Mullen, Harryette. "A Silence Between Us Like a Language: The Untranslatability of Experience in Woman Hollering Creek." MELUS 21.2 (Summer 1996): 8.

Parker, Holt M. "Toward a Definition of Popular Culture." History and Theory 50 (May, 2011): 147-70.

Pineda, Ana María, R.S.M. “Imagenes de Dios en el Camino: Retablos, Ex-Votos, Milagritos, and Murals." Theological Studies 55 (2004): 364-79.

Phelan, James. Experiencing Fiction: Judgments, Progressions, and the Rhetorical Theory of Narrative. Columbus: Ohio State University Press, 2007.

Pineda, Ana María, R.S.M. "Imagenes de Dios en el Camino: Retablos, Ex-Votos, Milagritos, and Murals." Theological Studies 55 (2004): 364-79.

Rebolledo, Tey Diana. Women Singing in the Snow: A Cultural Analysis of Chicana Literature. Tucson: University of Arizona Press, 1995.

Rivera, Carmen Haydée. Border Crossings and Beyond: The Life and Works of Sandra 
Ciseros. Greenwood Publishing Group/Santa Barbara: ABC-CLIO, 2009. [See pp. 42-51 for Rivera's main discussion of Woman Hollering Creek.]

Ross, Alex. "The Naysayers: Walter Benjamin, Theodor Adorno, and the Critique of Pop Culture." The New Yorker. September 15, 2014. Web: http://www.newyorker.com/magazine/2014/09/15/naysayers.

Spoturno, María Laura. "La traducción literal como estrategia desterritorialización y caso especial de alternancia des lenguas en Woman Hollering Creek de Sandra Cisneros." ["Literal Translation as Strategy of Deterritorialization and Special Case of Code-Switching in Sandra Cisneros' Woman Hollering Creek."] Trans: revista de traductología 14 (January 2010): 63-82. [Málaga, Spain.] 